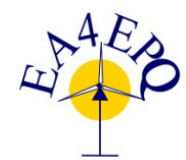

International Conference on Renewable Energies and Power Quality (ICREPQ'14)

Cordoba (Spain), $8^{\text {th }}$ to $10^{\text {th }}$ April, 2014

Renewable Energy and Pourer Quality. Fournal (RE\&PQJ)

ISSN 2172-038 X, No.12, April 2014

\title{
Working Prototype of Magnesium Batteries for Cell Phone and Cars and Magnesium Recycling by Lasers for Renewable Energy Cycle
}

\author{
T. Yabe ${ }^{1,2}$, Y. Suzuki ${ }^{2}$ and Y. Satoh ${ }^{2}$ \\ ${ }^{1}$ Department of Mechanical Engineering and Sciences \\ Tokyo Institute of Technology \\ 2-12-1 Oh-okayama, Meguro-ku, Tokyo 152-8552 (Japan) \\ Phone/Fax number:+813 57342165, e-mail: yabe@mech.titech.ac.ip \\ ${ }^{2}$ Energy Genesis Cycle(EGC) Inc. \\ 3-29-8 Kitasennzoku, Ohta-ku, Tokyo 145-0062 (Japan) \\ Phone number:+81 36425 6240, Fax number:+81 364256241 \\ Email: ysuzuki57@gmail.com
}

\begin{abstract}
We report the present status of development of magnesium batteries. Working prototype for cell phone and cars are already prepared and tested. These batteries use film-type magnesium and the efficiency is very high leading to high current and battery becomes very compact. For larger output, it is already demonstrated that the one cell can achieve several tens $\mathrm{A}$ (ampere), which is applicable to automobiles, and will reach $100 \mathrm{~A}$ within a year. For smaller output, it can be compact and can drive a cell phone for one month without charging.
\end{abstract}

\section{Key words}

Magnesium, Recycle, Battery, Laser, Energy Carrier.

\section{Introduction}

There is no doubt that we need an energy cycle free of fossil fuels that otherwise emit greenhouse gases causing global warming. Although solar energy is the ultimate renewable energy source, it is far from fully realized. Furthermore, since sunlight is available only in the clear daytime, it cannot be an alternative to thermal power stations unless effective and large power storage systems are available.

We proposed the chemical potential of magnesium as such an energy reservoir. Heat and hydrogen from the reaction of magnesium with water are used for turbines, reciprocal engines, fuel cells, and so on. The remaining " ash," $\mathrm{MgO}$ or $\mathrm{Mg}(\mathrm{OH})_{2}$, has to be deoxidized in order to make the energy cycle renewable. The deoxidization process is driven by the energy from a solar-energy-pumped laser[1],[2], or a laser diode powered by a wind-power generator, or other sources. Since laser radiation can be focused into a small spot, a very high temperature exceeding $4000 \mathrm{~K}$, needed for $\mathrm{MgO}$ deoxidization can easily be obtained. Once such $\mathrm{MgO}$ deoxidization technology is developed, unsteady solar power can be stored in Mg form to provide a stable supply of energy(see Fig.1)[1]. This paper reports the current status of magnesium battery and discuss the possibility of commercial use..

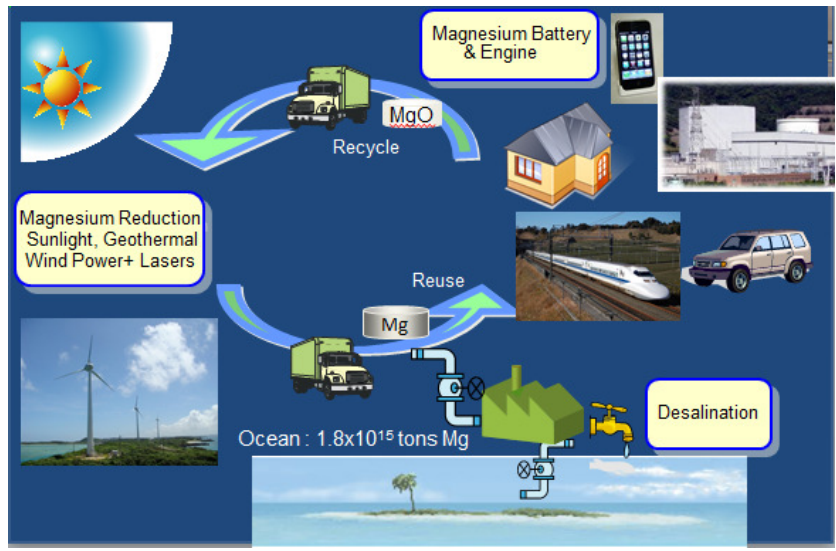

Fig.1 Magnesium is extracted from see water and is used for a battery or combustion engine. After the reaction, reaction residue $\mathrm{MgO}$ is refined back to magnesium by lasers produced by sunlight or other power sources.

\section{Magnesium Battery for Cell Phone}

We proposed a new battery using magnesium. The magnesium is used in the form of thin film and we achieved $1300 \mathrm{Ah} / \mathrm{kg}$ which is 9 times larger than $150 \mathrm{Ah} / \mathrm{kg}$ of Lithium-Ion battery.

Conventional magnesium air battery uses thick plate but after a surface layer is oxidized, rest of the part remains not reacted. This was the origin of low efficiency. Using 
thin layer of magnesium, however, almost all of the magnesium can be fully used(Fig.2).

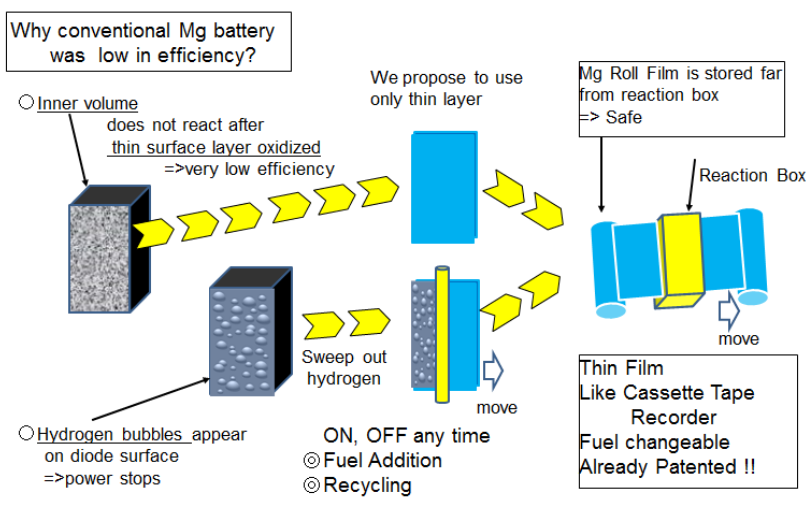

Fig.2. Film-type magnesium battery solves most of the difficulties of conventional magnesium battery.

There is alternative method to increase the efficiency using some chemical reaction to remove oxidized layer. However such reaction speed is always very slow compared with pure magnesium reaction. Therefore this makes the output electric current very small. For example, only $0.5 \mathrm{~A}$ is achieved with $5 \mathrm{~cm} \times 5 \mathrm{~cm}$ magnesium in such scheme, while $10 \mathrm{~A}$ is already achieved with the same area of thin film by our proposed new method.

In addition, using chemical reaction to remove oxidized layer means oxidized magnesium is mixed with electrolyte leading to degradation of conductivity as shown in Fg.3. Therefore frequent replacement of electrolyte is required. In our case, however, oxidized layer can be kept by some method and is not mixed with electrolyte.

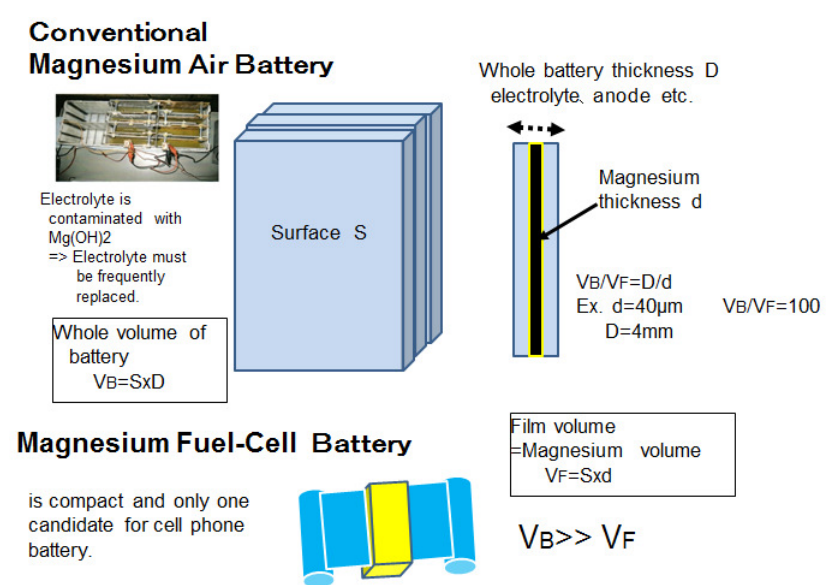

Fig.3. Film-type magnesium battery is a fuel-cell battery because it is separated from main battery.

Since fuel of magnesium is outside of reaction chamber, the size of whole battery becomes very compact. Let us consider a battery for cell phone.

The capacity of conventional cell phone is 1500-2000 $\mathrm{mAh}$. Since we already achieved $1300 \mathrm{~mA} / \mathrm{g}, 30 \mathrm{~g}$ of magnesium can drive cell phone during one month without charging. The size of $30 \mathrm{~g}$ magnesium is a cylinder of $5 \mathrm{~mm}$-high and $6.6 \mathrm{~cm}$-diameter and it can be installed inside cell phone.

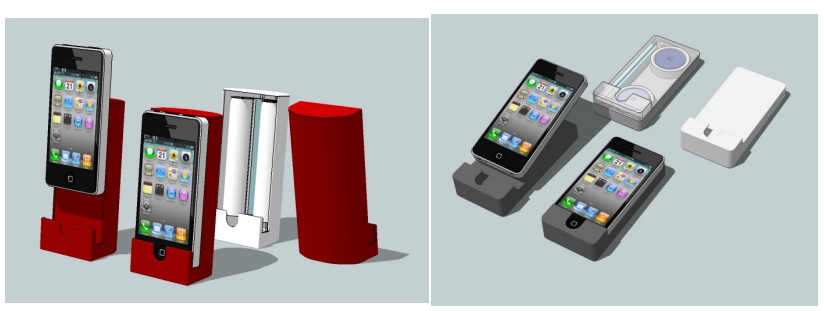

Figure 4 Magnesium fuel-cell battery is used as a cover and drives cell phone for a month without charging

\section{Magnesium Battery for Automobile}

Conventional cars, that use gasoline, can be pumped in the oil stations which independently scatter over a wide area like dots. If we use the rechargeable batteries like Lithium-Ion battery, the charging stations must be connected by electrical cables like lines. It is apparent that such line-connected system cannot cover a wide area(Fig.5)

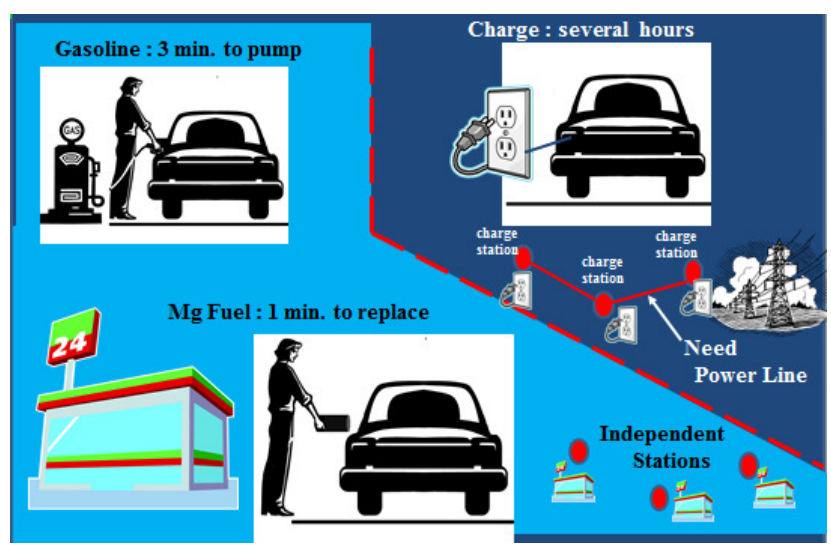

Figure 5. Dots (gasoline) and Lines(rechargeable battery)

The price of charging system is estimated to be 2,000 $\mathrm{USD} / \mathrm{kW}$. For the example of $50 \mathrm{~kW}$ charging, device costs 20,000USD and construction cost is 80,000USD, total is $100,000 \mathrm{USD}$. Thus it is $100,000 \mathrm{USD} / 50 \mathrm{~kW}$ $=2,000 \mathrm{USD} / \mathrm{kW}$.

For the mileage of $500 \mathrm{~km}$ by the standard-type car, $100 \mathrm{kWh}$ charging capacity is required. In order to charge the car within 30 minutes, we have to prepare $200 \mathrm{~kW}$ electricity for one car. If the above estimation is applied, we need 400,000USD. Considering overall charging and discharging efficiency, the cost goes up by 2 times that is 800,000 USD only for one car.

Even for shorter mileage of $200 \mathrm{~km}$ by the standard-type car, $50 \mathrm{kWh}$ charging capacity is required. If we charge the car at home, it takes 33 hours since usually the electric cable is $100 \mathrm{~V}$ and $15 \mathrm{~A}$ which gives $1.5 \mathrm{~kW}$. Usually the 
charging efficiency is not $100 \%$ and hence charging time is much longer.

Therefore, it is desirable to establish non-rechargeable battery that uses magnesium fuel like gasoline.

For larger size, we already developed a cell that can deliver more than $20 \mathrm{~A}$ and $10 \mathrm{~W}$ whose cell area is $170 \mathrm{~mm} \times 340 \mathrm{~mm}$ (Fig.6) and we shall develop a new cell of $300 \mathrm{~mm} \times 600 \mathrm{~mm}$ that can deliver $60 \mathrm{~A}$ and $30 \mathrm{~W}$ in 2014.

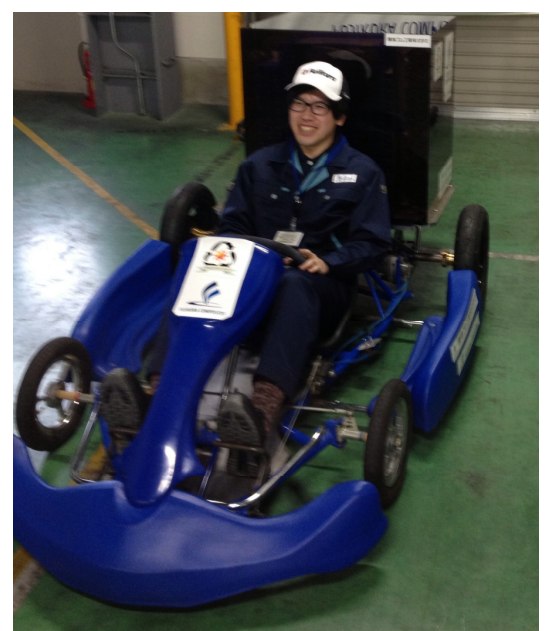

Figure 6 Magnesium fuel-cell battery for automobile whose total weight is $200 \mathrm{~kg}$. Collaboration with Fujikura Rubber Ltd.

By accumulating 100 of these cells, $3 \mathrm{~kW}$ model (peak power) will be finalized in 2014 with the size of $300 \mathrm{~mm} \mathrm{x}$ $600 \mathrm{~mm} \times 600 \mathrm{~mm}$. This size should be further reduced by improving battery efficiency and packing method. By this battery, we can drive an electric golf cart. 3 modules of this battery can drive a car for one person.

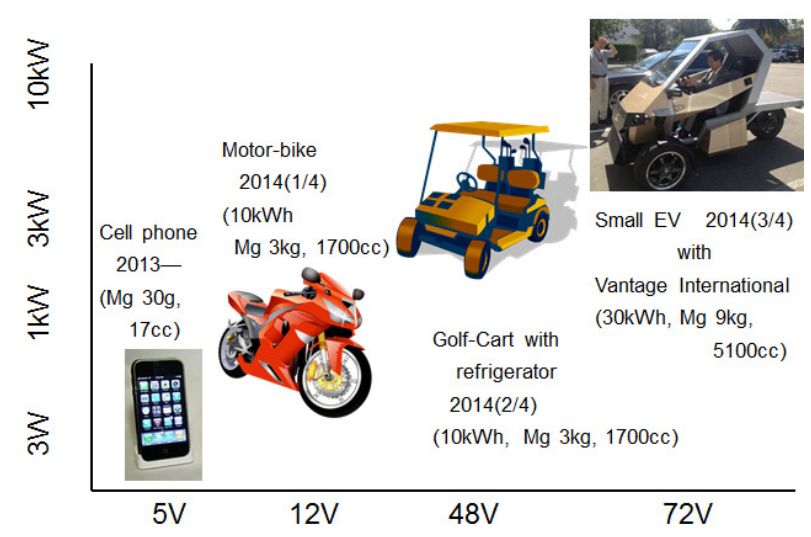

Figure 7 Development schedule of magnesium fuel-cell battery for various use.

\section{Magnesium Recycling by Lasers}

Reaction product in magnesium battery is refined back to pure magnesium by lasers. Using $1 \mathrm{~kW} \mathrm{CO} 2$ laser, we already succeeded in producing $15 \mathrm{mg} / \mathrm{kJ}$ [3] and $20 \mathrm{mg} / \mathrm{kJ}$ with $4 \mathrm{~kW}$ semiconductor laser. This means $50 \mathrm{~kJ}$ is used to get $1 \mathrm{~g}$ of magnesium. Since magnesium of $1 \mathrm{~g}$ releases the energy of $25.2 \mathrm{~kJ}$, the above efficiency of magnesium recovery is $50 \%$.

Currently we have $8 \mathrm{~kW}$ semiconductor laser which can produce 5 tons of magnesium per year. Since magnesium battery reached $60 \%$ of theoretical limit $7 \mathrm{kWh} / \mathrm{kg}$ in laboratory experiment, magnesium of $24 \mathrm{~kg}$ generate $100 \mathrm{kWh}$ sufficient for $500 \mathrm{~km}$ mileage of medium-sized car. Therefore $8 \mathrm{~kW}$ laser can support 208 cars $\mathrm{x} 500 \mathrm{~km}$ mileage in one year

$8 \mathrm{~kW}$ laser that can provide 5 tons of magnesium/year can support the battery for 13,000 cell phones in one year. If 3 billion people use magnesium battery for cell phones, we need to produce magnesium of 1 million tons every year. Since current magnesium production is 0.6 million tons/year, we need to establish magnesium production plants before selling cell phone battery.

For commercial plant, we can start with the combination of wind power generator, geothermal power plant, hydraulic power plant and semi-conductor lasers. Solar pumped laser should come later after the output reaches $400 \mathrm{~W}$ because it is cheap and directly uses solar energy. The latest maximum output from solar pumped laser is $120 \mathrm{~W}$ and $400 \mathrm{~W}$ is within a reach as shown in the next section.

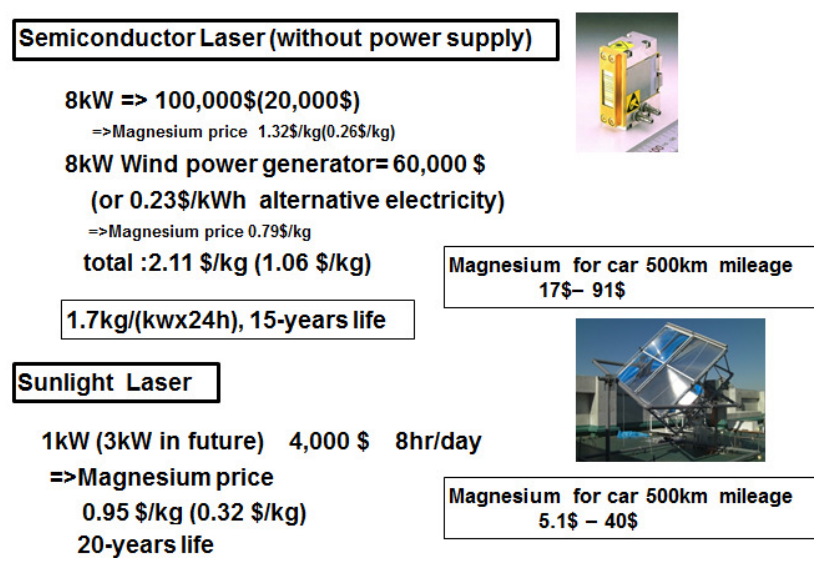

Figure 8 Estimated magnesium price with semiconductor laser and solar-energy-pumped laser.

\section{References}

[1] T.Yabe et.al., " Demonstrated Fossil-Fuel-Free Energy Cycle Using Magnesium and Laser" , Appl.Phys.Lett. 89 (2006) 261107-1-3

[2] T. H. Dinh, T. Ohkubo and T. Yabe, “ 120 watt continuous wave solar-pumped laser with a liquid light-guide lens and an Nd:YAG rod" , Optics Letters, Vol. 37,(2012) pp.2670-2672

[3] S. H. Liao, T. Yabe et.al.," Laser-induced Mg production from magnesium oxide using Si-based agents and Si-based agents recycling" , J.Appl.Phys.Vol.109 (2011) 013103 